\title{
Kumlu Tın Bünyeli Bir Toprağın C ve N-Dinamiği Üzerine Ham ve Arıtılmıș Zeytin Karasuyunun Etkileri
}

\section{Onur BAYIZ '(D), Nur OKUR*'}

\author{
' Ege Üniversitesi Ziraat Fakültesi Toprak Bilimi ve Bitki Besleme Bölümü, İzmir.
}

Öz: Zeytin karasuyu, yüksek kirlilik yükü ve içerdiği polifenollerden dolayı fitotoksik etkilere sahip fakat bununla beraber organik bileșikler ve bitki besin elementleri yönünden de zengin bir atık su özelliğindedir. Bu nedenle belli düzeyde bir arıtımdan geçtikten sonra toprak ıslah maddesi olarak kullanılabilme potansiyeli bulunmaktadır. Bu çalıșmada; zeytinyağı üretimi sırasında ortaya çıkan ham karasu ve iki farklı yöntem (ekonomik ön arıtma ve ileri arıtma tekniği) ile arıtılmıș karasu kumlu tın bünyeli bir toprağa 50 , 100 ve $150 \mathrm{~m}^{3}$ ha-1 dozlarında uygulanmıș ve toprağın $C$ ve $\mathrm{N}$-dinamiği ile bazı kimyasal özelliklerinde meydana getirdiği değișimler incelenmiștir. Deneme laboratuvar koșullarında 90 günlük bir inkübasyon denemesi olarak yürütülmüștür. Gerek arıtılmıș ve gerekse arıtılmamıș zeytin karasu uygulamaları toprağın toplam organik-C (TOC), toplam N (TON), çözünebilir-C (ÇÖZ-C), mikrobiyal biyokütle-C ve-N (MB-C ve MB-N), alınabilir $P$ ve $K$ miktarlarını artırmıș fakat N-immobilizasyonundan dolayı inorganik-N (iNOR-N) havuzunu küçültmüștür. En yüksek MBC/TOC, ÇÖZ-C/TOC ve MB-N/TON oranları karasu uygulamalarının ilk dozlarında, en yüksek iNOR-N/TON oranları ise, kontrol ve en yüksek ham karasu uygulamalarında saptanmıștır. Bu sonuçlar karasuyun 50 ve $100 \mathrm{~m}^{3} \mathrm{ha}^{-1}$ uygulamalarında topraktaki mikrobiyal biyokütlenin arttığını fakat $150 \mathrm{~m}^{3} \mathrm{ha}^{-1}$ karasu uygulamasında topraktaki $\mathrm{C}$ ve $\mathrm{N}$-dinamiğinin olumsuz

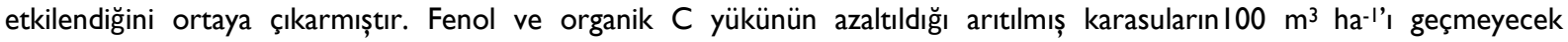
dozlardaki uygulamalarının bu atığın değerlendirilmesinde iyi bir geri dönüșüm stratejisi olabileceği düșünülmektedir.

Anahtar Kelimeler: mikrobiyal biyokütle, toprağın C ve N-dinamiği, zeytin karasuyu

\section{The Effects of Treated and Untreated Oil Mill Wastewater on C and N-Dynamics of a Sandy Loam Soil}

\begin{abstract}
Olive mill wastewater (OMW) is characterized by high pollutant load and phytotoxic levels of polyphenols, but also a high amount of organic compounds and plant mineral nutrients. For this reason, there is a potential to be used as a material improving soil after treated. In this study, OMW treated with two different treatment processes (economic pre-treatment and advanced treatment process) and untreated OMW were applied to a sandy loam texture soil at the rates of $0,50,100,150 \mathrm{~m}^{3} \mathrm{ha}^{-1}$ and the changes in C-and $\mathrm{N}$-dynamics of soil and some chemical properties were determined. The experiment was carried out in total period of 90 days of incubation under laboratory conditions. Amendment with untreated and treated wastewaters increased the contents of total organic $C$ (TOC), total N (TON), soluble- C (SOL-C), microbial biomass-C and N (MB-C and MB$N)$ and available $P$ and $K$, but inorganic-N (INOR-N) pool decreased due to $N$-immobilization. The highest the ratios of MB-C/TOC, SOL-C/TOC and MB-NITON were determined at the low OMW rates and the highest INOR-N/TON at the control and highest untreated OMW rate. These results showed that microbial biomass increased at 50 and $100 \mathrm{~m}^{3} \mathrm{ha}^{-1}$ OMW rates but C-and N-dynamics of soil negatively were affected by $150 \mathrm{~m}^{3}$ ha-1 OMW applications. The fact that OMW that are minimized phenol and organic Cload are applied to soils at not exceeding $100 \mathrm{~m}^{3}$ ha-1 rate may be considered to be a good strategy for recycling this waste.
\end{abstract}

Keywords: microbial biomass, C- and N dynamics of soil, olive mill wastewater

\section{GiRiș}

Akdeniz ülkeleri yaklașık 10 milyon ha dikili alanı ile dünya zeytin üretiminin \%97'sini olușturmaktadır. Zeytinyağı üretimi gerçekleștiren bașlıca ülkeler íspanya (\%4I), Italya (\%|3), Yunanistan (\%9.8), Tunus (\%6.9), Suriye (\%6.I) ve Türkiye'dir (\%5.8) (FAO, 2016). Ülkemizde yağlık zeytin üretimi 2006 ila 2010 yılları arasında \% 100 'lük bir artıșla $1,200,000$ tona, zeytinyağı tüketimi de 2003-2010 yılları arasında \% II3'lük bir artıșla 98,000 tona ulașmıștır (Anonim, 2015). Bu büyüyen endüstri söz konusu ülkeleri, zeytinyağı üretimi sırasında ortaya çıkan atıkların pratik ve ekonomik olarak değerlendirilmesine yönelik ciddi çevre problemleri ile karșı karșıya bırakmaktadır. Türkiye'deki zeytinyağı tesislerinde, sezonda ortalama toplam $775.000 \mathrm{~m}^{3}$ su kullanıldığı, buna karșın $923,000 \mathrm{~m}^{3}$ atıksu oluștuğu tahmin edilmektedir (Hocaoğlu, 2015). Zeytin karasuyunun tarım toprakları açısından en büyük tehlikesi yüksek organik yükü ve fitotoksik ve antibakteriyal özelliklere sahip fenol içeriğidir (Mekki ve ark., 2006). Bununla beraber diğer endüstriyel atık sulardan farklı olarak karasu sadece zeytin meyvesine ait bileșenler ile sudan olușmakta ve herhangi bir sentetik madde içermemektedir. Ayrıca karasuyun organik madde, N, P, $\mathrm{K}$ ve Mg'ca zengin olması nedeniyle belli düzeyde bir arıtımdan geçtikten sonra yararlı bir gübre veya toprak ıslah maddesi özelliği kazanabilme potansiyeli bulunmaktadır (Tsagaraki ve ark., 2007). Bu atığın bir çevre sorunu olduğu ülkelerde arıtılmamıș karasu uygulamalarının, toprak özellikleri ve bitki gelișimi

Sorumlu Yazar: nur.okur@ege.edu.tr Bu çalșma yüksek lisans tezi ürünü olup Ege Üniversitesi Bilimsel Araștırma Projeleri Koordinasyon Birimi tarafindan desteklenmiștir.

Geliș Tarihi: 18 Ağustos 2017

Kabul Tarihi: 30 Mayıs 2018 
üzerine etkilerini araștıran pek çok çalıșma yapılmıștır (Piotrowska ve ark., 2006; Sierra ve ark., 2007; Mechri ve ark., 2009). Bu çalıșmalar arıtılmamıș karasuyun toprağa uygulanmasında gerek bitki gelișimi ve gerekse toprak özellikleri açısından bir takım zararlı etkilerin ortaya çıkabileceğini göstermektedir. Bununla beraber toprağın tamponlama kapasitesi ve mikrobiyal aktivitesine bağlı olarak karasuyun zararlı etkileri zaman içerisinde azalabilmektedir. Arıtılmış zeytin karasuyunun tarım topraklarında kullanımı ile ilgili çalıșmalarda ise genellikle en ucuz ve en kolay uygulanabilir yöntemler seçilmiștir. Moraetis ve ark. (20II); zeytin karasuyunu kireç ile karıștırıp ön-arıtma yaptıktan sonra 5 yıl süre ile normal su ile karıștırıp, sulama sezonu boyunca mısırda kullanmıșlardır. Çalıșma sonunda mısır bitkisinin çiftçi koșullarında uygulanan gübrelere oranla azotu 6 kat ve potasyumu ise 50 kat daha fazla, fosforu ise 2 kat daha az aldığı belirlenmiștir. Brunetti ve ark. (2007); katalizör olarak $\mathrm{MnO}_{2}$ ilave edilerek arıtılmış ve hiç arıtılmamış, karasuyu 300 ve $600 \mathrm{~m}^{3} \mathrm{ha}^{-1}$ dozlarında topraklara uygulamıșlar ve her iki uygulamanın da toprağın EC'sini, toplam organik ve ekstrakte edilebilir karbonunu, humifike olmuș ve olmamıș $C$ formlarını, yarayıșlı $P$ ve $K$ miktarlarını artırdığını saptamıșlardır. Piotrowska ve ark. (20II); karasuyu defenolize ettikten sonra $80 \mathrm{~m}^{3}$ ha'düzeyinde bir toprağa uygulamıșlardır. Karasu toprağın biyolojik özelliklerinde ilk 14 gün içerisinde ani değișimlere neden olmuș, fakat daha sonra kendini toparlayarak ilk değerlerine geri dönmüștür. Araștırma sonucunda; fenol bileșikleri uzaklaștırıldıktan sonra karasuyun organik maddece fakir ve yarı kurak bölge topraklarında restore edici bir katkı maddesi olarak uygulanabileceği vurgulanmıștır. Ülkemizde Atıksu
Kontrol Yönetmeliği'ne göre karasuyun doğrudan su kaynaklarına boșaltılması yasak olup, zeytinyağı üreticilerinden arıtma tesisi kurmaları veya buharlaștırma lagünleri olușturmaları istenmektedir. Yapılan bir anket çalıșmasına göre, 129 zeytinyağı üreticisinden sadece 3 tanesinin böyle bir tesise sahip olduğu belirlenmiștir (Yay ve ark., 20I2). Yurdumuz topraklarının organik maddece fakir olması, çeșitli organik atıkların değerlendirilmesini gerektirmektedir. Bu çalıșmada; zeytinyağı üretimi sırasında ortaya çıkan ham karasu ile iki farklı yöntem (ekonomik ön arıtma ve ileri arıtma tekniği) ile arıtılmıș karasuyun hafif bünyeli (kumlu tın) bir toprağa 50, 100 ve $150 \mathrm{~m}^{3} \mathrm{ha}^{-1}$ dozlarında uygulanması ile toprağın biyokimyasal özelliklerinde meydana gelen değișimler incelenmiș ve bu değișimlerin toprak verimliliği açısından etkileri değerlendirilmiștir.

\section{MATERYAL ve YÖNTEM}

\section{Materyal}

Proje materyali zeytin karasuyu, Aydın ilinde 3 fazlı sistem ile zeytinyağı ekstraksiyonu yapan bir ișletmeden alınmıștır. Karasu arıtma ișlemi Dokuz Eylül Üniversitesi Çevre Mühendisliği Bölümünde 2 farklı yöntem (ekonomik ön arıtma ve ileri arıtma) kullanılarak yapılmıștır. Ekonomik arıtmada I litre karasuya $40 \mathrm{gr}$ $\mathrm{Ca}(\mathrm{OH})_{2}$ ilave edildikten sonra 2 dakika hızlı ve 15 dakika yavaș karıștırma yapıımıș ve daha sonra 24 saatlik çökelmeye bırakılmıștır. Ileri arıtmada ise karasu nano$\mathrm{Fe}_{3} \mathrm{O}_{4} / \mathrm{SiO}_{2}$ kullanılarak UV altında fotokatalitik oksidasyonla arıtılmıștır. Çalıșmada kullanılan karasuların bazı kimyasal özellikleri Çizelge I'de verilmiștir.

Ekonomik yöntemle arıtılmıș suyun pH'sı $\mathrm{Ca}(\mathrm{OH})_{2}$ kullanılması nedeniyle $10.5 \mathrm{l}$ 'e çıkmıș fakat ileri arıtma ile

Çizelge I. Ham karasu (H), ekonomik (E) ve ileri arıtma (I) yöntemleri ile arıtılmıș zeytin karasuların kimyasal özellikleri

\begin{tabular}{llll} 
& $\mathrm{H}$ & $\mathrm{E}$ & $\mathrm{i}$ \\
\hline $\mathrm{PH}$ & 4.93 & $10.5 \mathrm{I}$ & 4.44 \\
$\mathrm{EC}\left(\mathrm{dS} \mathrm{m}{ }^{-1}\right)$ & 7.26 & 10.49 & 13.63 \\
Top. Org. C $\left(\mathrm{g} \mathrm{I}^{-1}\right)$ & 27.0 & 16.0 & 18.3 \\
Toplam N $\left(\mathrm{g} \mathrm{I}^{-1}\right)$ & 0.33 & 0.04 & 0.05 \\
Toplam P $\left(\mathrm{g} \mathrm{I}^{-1}\right)$ & 0.63 & 0.02 & 0.04 \\
Toplam K $\left(\mathrm{g} \mathrm{I}^{-1}\right)$ & 3.52 & 5.68 & 5.11 \\
C/N Oranı & 82 & 432 & 366 \\
Toplam Fenol $\left(\mathrm{g} \mathrm{l}^{-1}\right)$ & 0.66 & 0.09 & 0.26
\end{tabular}

arıtılan suyun pH'sı (4.44) fazla değișmemiștir. Ham karasuyun elektriksel iletkenliği arıtmadan sonra yükselmiș, toplam organik $C$ miktarı ise ortalama \%36 azalmıștır. Toplam $\mathrm{N}$ ve $\mathrm{P}$ miktarları arıtmadan sonra ortalama \%88 ve \%95 oranında azalırken, toplam K içeriği ise ortalama \%53 artmıștır. Arıtmadan sonra karasuların $\mathrm{C} / \mathrm{N}$ oranları da artıș göstermiștir. Toksik bir bileșik olan toplam fenol miktarı ham karasuya oranla 26 ekonomik yolla arıtılmıș karasuda \%86, ileri yöntemle arıtıımıș karasuda ise $\% 60$ oranında giderilmiștir.

Projede diğer deneme materyali olarak kullanılan toprak ise Menemen ovasında yer alan Ege Üniversitesi Ziraat Fakültesi Araștırma, Uygulama ve Üretme Çiftliği'nden alınmıștır. Deneme toprağının bazı fiziko-kimyasal özellikleri ise Çizelge 2'de verilmiștir. 
Çizelge 2. Deneme toprağının bazı fiziksel ve kimyasal özellikleri

\begin{tabular}{ll}
\hline $\mathrm{PH}$ & $7.5 \mathrm{I}$ \\
$\mathrm{EC}\left(\mathrm{dS} \mathrm{m}{ }^{-1}\right)$ & 0.57 \\
$\mathrm{CaCO}_{3}(\%)$ & 4.36 \\
$\mathrm{Kum}(\%)$ & 55.75 \\
$\mathrm{Kil}(\%)$ & 18.83 \\
Mil $(\%)$ & 25.42 \\
Bünye & Kumlu Tın \\
Organik Madde (\%) & 1.82 \\
Toplam C $\left(\mathrm{g} \mathrm{kg-1}^{-1}\right)$ & 10.6 \\
Toplam N $\left(\mathrm{g} \mathrm{kg}^{-1}\right)$ & 1.3 \\
Alınabilir P $\left(\mathrm{mg} \mathrm{kg}^{-1}\right)$ & 12.24 \\
Alınabilir K $\left(\mathrm{mg} \mathrm{kg}^{-1}\right)$ & 546.82
\end{tabular}

Hafif alkalin reaksiyon gösteren deneme toprağı, elektriksel geçirgenlik açısından tuzluluk tehlikesi bulundurmamaktadır. Kumlu tın bünyeye sahip olan toprak, organik maddece düșük ve kireçli olarak sınıflandırılmıștır. Bitki besin maddeleri açısından ele alındığında ise; toplam azotça zengin, alınabilir potasyum fazla, alınabilir fosfor açısından ise yeterli düzeydedir.

Yöntem

İnkübasyon denemesi olarak yürütülen çalıșmada $24 \times 25 \times 20 \mathrm{~cm}$ boyutlarındaki plastik saksılara I,250 gr toprak tartılmış ve $125 \mathrm{ml}$ saf su ile nemlendirilmiștir. Daha sonra topraklara 50,100 ve $150 \mathrm{~m}^{3} \mathrm{ha}^{-1}$ dozunda karasu uygulaması yapılmıștır. Kontrol saksılarına ise aynı miktarda saf su uygulanmıștır. Deneme 3 tekerrürlü olarak toplam 36 saksıda yürütülmüștür. Uygulama konuları șu șekilde belirlenmiștir; Kontrol (K); $50 \mathrm{~m}^{3} \mathrm{ha}^{-1}$ ham, ekonomik ve ileri arıtma uygulamaları (HI, EI ve il); $100 \mathrm{~m}^{3} \mathrm{ha}^{-1}$ ham, ekonomik ve ileri arıtma uygulamaları $\left(\mathrm{H} 2\right.$, E2 ve i2) ve $150 \mathrm{~m}^{3} \mathrm{ha}^{-1}$ ham, ekonomik ve ileri arıtma uygulamaları (H3, E3 ve i3). Uygulamaları yapılan topraklar $25^{\circ} \mathrm{C}$ 'de inkübatörde bırakılarak, su tutma kapasitesinin \%55-60 arasındaki toprak nemi deneme boyunca sabit tutulmuștur. Toplam 3 ay sonra alınan nemli toprak örnekleri 2 mm'lik elekten geçirildikten sonra mikrobiyolojik analizler tamamlanıncaya kadar $+4{ }^{\circ} \mathrm{C}$ 'de muhafaza edilmișlerdir. Mikrobiyolojik analizler nemli toprak örneklerinde, fiziko-kimyasal analizler ise hava kurusu hale getirilen ve 2 mm'lik elekten geçirilen örneklerde gerçekleștirilmiștir. Toprak örneklerinde bünye (Bouyoucos, 1992), $\mathrm{pH}$ (Jackson, 1967), elektriksel iletkenlik (Anonim, 1978), kireç (Schlichting ve Blume, 1966), organik madde ve toplam organik C (Rauterberg ve Kremkus, I95I) ve (Black, 1965), toplam azot (Bremner, 1965), alınabilir P ise Olsen ve Sommers (1982)'e göre belirlenmiștir. Çözünebilir organik C Jones ve Willett (2006)'e göre saptanmıș, toprakların inorganik azot miktarları ise $\mathrm{NH}_{4}$ $\mathrm{N}+\mathrm{NO}_{3}-\mathrm{N}$ 'u toplamından elde edilmiștir. Toprakların $\mathrm{NH}_{4}-\mathrm{N}$ ' u 660 nm' de (Kandeler ve Gerber, 1988), $\mathrm{NO}_{3}-\mathrm{N}^{\prime} \mathrm{u}$ ise UV-absorbsiyon ile $210 \mathrm{~nm}$ ' de kolorimetrik olarak belirlenmiștir (Scharpf ve Wehrmann, 1976). Toprakların alınabilir $\mathrm{Ca}, \mathrm{Na}$ ve $\mathrm{K}$ miktarları I $\mathrm{N} \mathrm{NH}$ OAc ( $\mathrm{pH}$ 7) ile çalkalanarak elde edilen süzüklerde alev fotometrede (Pratt, 1965), alınabilir $\mathrm{Fe}, \mathrm{Cu}$, ve $\mathrm{Zn}$ miktarları ise DTPA $+\mathrm{CaCl}_{2}+\mathrm{TEA}$ $(\mathrm{pH}$ 7.3) ile ekstrakte edilen topraklarda atomik absorbsiyon spektrofotometre kullanılarak saptanmıștır (Lindsay ve Norvell, 1978). Mikrobiyal biyokütle C ve N analizleri fumigasyon-ekstraksiyon yöntemi ile (Vance ve ark., 1987) belirlenmiștir. Araștırmada elde edilen sonuçların değerlendirmelerinde SPSS 12.0 istatistik paket programı kullanılarak varyans analizi yapılmıs, olușan farklılıklar Duncan testine göre belirlenmiștir.

\section{BULGULAR ve TARTIȘMA}

\section{Zeytin Karasu Uygulamalarının Toprağın C - Dinamiği Üzerine Etkisi}

Zeytin karasu uygulamaları toprakların toplam organik-C (TOC) içeriklerini kontrole oranla \%2 ila \% I5 arasında artırmıștır (Çizelge 3). En yüksek TOC içerikleri H2, H3, E3 ve i3 uygulamalarında saptanmıștır. En düșük TOC içeriği ise kontrol toprakta ortaya çıkmıștır. Karasu uygulamaları toprağın labil $\mathrm{C}$ kaynakları olan mikrobiyal biyokütle-C (MB-C) ve çözünebilir-C (ÇÖZ-C) miktarlarını da istatistiki anlamda etkilemiștir. En yüksek MB-C miktarları en düșük karasu uygulamalarında $(\mathrm{HI}$, El ve II), en düșük MB-C miktarı ise kontrol örnekte saptanmıștır. Karasu dozlarının artıșına bağlı olarak MB-C miktarlarında bir azalma kaydedilmiștir. ÇÖZ-C miktarları incelendiğinde de $\mathrm{HI}, \mathrm{H} 2, \mathrm{El}$ ve il uygulamalarının en yüksek ÇÖZ-C miktarlarına sahip olduğu görülmektedir. En düșük ÇÖZ-C miktarları ise $\mathrm{K}$, E3 ve i3 uygulamalarında belirlenmiștir.

Labil C kaynaklarının, toplam organik karbona oranları da hesaplanmıș ve sonuçlar yine Çizelge 3'de verilmiștir. En yüksek MB-C/TOC ve ÇÖZ-C/TOC oranları karasu uygulamalarının ilk dozlarında, en düșük oranlar ise kontrol ve en yüksek karasu uygulamalarında saptanmıștır. MB-C/TOC oranları \%l.08 ila \%।.62 arasında, ÇÖZ-C/TOC oranları ise \%0.09 ila \%0.19 arasında değișmiștir.

Araștırma sonuçları, zeytin karasu uygulamalarının toprağın TOC içeriğini artırdığını ortaya çıkarmıștır. Benzer sonuçlar bazı araștırıcılar tarafından da bulunmuștur (Piotrowska ve ark., 2006; Mekki ve ark., 
Çizelge 3. Karasu uygulamalarının toplam organik-C (TOC), mikrobiyal biyokütle-C (MB-C) ve çözünebilir-C (ÇÖZ-C) ile MB-C/TOC ve ÇÖZ-C/TOC oranları üzerine etkisi

\begin{tabular}{llllll}
\hline Uyg. & $\begin{array}{l}\text { TOC } \\
\left(\mathrm{g} \mathrm{kg}^{-1}\right)\end{array}$ & $\begin{array}{l}\text { MB-C } \\
(\mathrm{mg} \mathrm{kg}-1)\end{array}$ & $\begin{array}{l}\text { ÇÖZ-C } \\
\left(\mathrm{mg} \mathrm{kg}^{-1}\right)\end{array}$ & $\begin{array}{l}\text { MB-C/TOC } \\
(\%)\end{array}$ & $\begin{array}{l}\text { ÇÖZ-C/TOC } \\
(\%)\end{array}$ \\
\hline $\mathrm{K}$ & $10.8 \mathrm{c}^{*}$ & $128 \mathrm{~d}^{*}$ & $10.3 \mathrm{~b}^{*}$ & $1.18 \mathrm{~d}^{*}$ & $0.09 \mathrm{c}^{*}$ \\
$\mathrm{HI}$ & $11.7 \mathrm{~b}$ & $186 \mathrm{a}$ & $21.8 \mathrm{a}$ & $1.59 \mathrm{a}$ & $0.19 \mathrm{a}$ \\
$\mathrm{H} 2$ & $12.0 \mathrm{a}$ & $153 \mathrm{~b}$ & $20.4 \mathrm{a}$ & $1.27 \mathrm{c}$ & $0.17 \mathrm{ab}$ \\
$\mathrm{H} 3$ & $12.5 \mathrm{a}$ & $135 \mathrm{c}$ & $16.1 \mathrm{ab}$ & $1.08 \mathrm{~d}$ & $0.13 \mathrm{~b}$ \\
$\mathrm{EI}$ & $11.6 \mathrm{~b}$ & $172 \mathrm{a}$ & $18.3 \mathrm{a}$ & $1.48 \mathrm{ab}$ & $0.16 \mathrm{a}$ \\
$\mathrm{E} 2$ & $11.8 \mathrm{~b}$ & $165 \mathrm{~b}$ & $12.5 \mathrm{ab}$ & $1.39 \mathrm{~b}$ & $0.11 \mathrm{~b}$ \\
$\mathrm{E} 3$ & $12.2 \mathrm{a}$ & $142 \mathrm{bc}$ & $10.5 \mathrm{~b}$ & $1.16 \mathrm{~d}$ & $0.09 \mathrm{c}$ \\
iI & $11.2 \mathrm{~b}$ & $182 \mathrm{a}$ & $19.3 \mathrm{a}$ & $1.62 \mathrm{a}$ & $0.17 \mathrm{a}$ \\
i2 & $11.6 \mathrm{~b}$ & $169 \mathrm{~b}$ & $14.2 \mathrm{ab}$ & $1.45 \mathrm{ab}$ & $0.12 \mathrm{~b}$ \\
i3 & $12.2 \mathrm{a}$ & $139 \mathrm{c}$ & $10.6 \mathrm{~b}$ & $1.13 \mathrm{~d}$ & $0.09 \mathrm{c}$ \\
\hline
\end{tabular}

*: Uygulamalar arasındaki farklar \% I seviyesinde istatistiki olarak önemli bulunmuștur

2006). Artan uygulama miktarına bağlı olarak toprağa giren organik C miktarının arttığı anlașılmaktadır. Daha fazla TOC içeriğine sahip olan ham karasu uygulamaları genelde toprakta da daha fazla TOC artıșına neden olmuștur. Bununla beraber bu durum MB-C miktarlarına yansımamıș ve en yüksek MB-C miktarları en düșük karasu uygulamalarında ortaya çıkmıștır. Bu sonuçlar, söz konusu uygulamalarda mikroorganizmaların daha yüksek bir aktiviteye sahip olduğu ve organik madde ile labil organik karbonun daha fazla dekompozisyona uğradığını göstermektedir. Benzer sonuçlar Demisie ve ark. (2014) tarafindan da bulunmuș ve uygulanan biyokömür miktarlarının artıșına bağlı olarak topraktaki TOC miktarlarının artmasına karșılık, en yüksek MB-C değerlerinin en düșük biyokömür uygulamalarında ortaya çıktığını saptamıșlardır. MB-C dıșında toprağın diğer bir labil fraksiyonu olan ÇÖZ-C, toprak mikroorganizmalarının ana enerji kaynağıdır (Huang ve Song, 2010). Bu parametreye ait sonuçlar da MB-C miktarlarına paralellik göstermiș ve en düșük karasu dozlarında daha yüksek ÇÖZ-C konsantrasyonları saptanmıștır. Toprak organik maddesinin labil fraksiyonlarını olușturan MB-C ve ÇÖZ-C, kolaylıkla

Çizelge 4. Karasu uygulamalarının toplam $N(T O N)$, mikrobiyal biyokütle-N(MB-N) ve inorganik-N (iNOR-N) ile MBN/TON ve INOR-N/TON oranları üzerine etkisi

\begin{tabular}{llllll}
\hline Uyg. & $\begin{array}{l}\text { TON } \\
\left(\mathrm{g} \mathrm{kg}^{-1}\right)\end{array}$ & $\begin{array}{l}\text { MB-N } \\
(\mathrm{mg} \mathrm{kg-1})\end{array}$ & $\begin{array}{l}\text { iNOR-N } \\
(\mathrm{mg} \mathrm{kg})^{-1}\end{array}$ & $\begin{array}{l}\text { MB-N/TON } \\
(\%)\end{array}$ & $\begin{array}{l}\text { iNOR-N/TON } \\
(\%)\end{array}$ \\
\hline $\mathrm{K}$ & $1.3 \mathrm{l} \mathrm{c}$ & $66 \mathrm{~b}^{*}$ & $5.19 \mathrm{a}^{*}$ & $5.03 \mathrm{~b}^{*}$ & $0.39 \mathrm{a}^{*}$ \\
$\mathrm{HI}$ & $1.34 \mathrm{bc}$ & $14 \mathrm{a}$ & $4.18 \mathrm{~b}$ & $10.52 \mathrm{a}$ & $0.3 \mathrm{~b}$ \\
$\mathrm{H} 2$ & $1.38 \mathrm{~b}$ & $132 \mathrm{a}$ & $4.37 \mathrm{~b}$ & $9.56 \mathrm{a}$ & $0.32 \mathrm{~b}$ \\
$\mathrm{H} 3$ & $1.42 \mathrm{a}$ & $75 \mathrm{ab}$ & $4.83 \mathrm{ab}$ & $5.28 \mathrm{~b}$ & $0.34 \mathrm{ab}$ \\
$\mathrm{EI}$ & $1.35 \mathrm{bc}$ & $128 \mathrm{a}$ & $4.12 \mathrm{~b}$ & $9.48 \mathrm{a}$ & $0.30 \mathrm{~b}$ \\
$\mathrm{E} 2$ & $1.37 \mathrm{~b}$ & $123 \mathrm{a}$ & $4.20 \mathrm{~b}$ & $8.97 \mathrm{a}$ & $0.3 \mathrm{~b}$ \\
$\mathrm{E} 3$ & $1.39 \mathrm{~b}$ & $84 \mathrm{~b}$ & $4.22 \mathrm{~b}$ & $6.04 \mathrm{~b}$ & $0.30 \mathrm{~b}$ \\
II & $1.37 \mathrm{~b}$ & $115 \mathrm{a}$ & $3.83 \mathrm{c}$ & $8.39 \mathrm{a}$ & $0.28 \mathrm{~b}$ \\
i2 & $1.37 \mathrm{~b}$ & $75 \mathrm{ab}$ & $4.04 \mathrm{bc}$ & $6.47 \mathrm{ab}$ & $0.29 \mathrm{~b}$ \\
i3 & $1.39 \mathrm{~b}$ & $83 \mathrm{ab}$ & $4.21 \mathrm{~b}$ & $5.97 \mathrm{~b}$ & $0.30 \mathrm{~b}$ \\
\hline
\end{tabular}

*: Uygulamalar arasındaki farklar \% I seviyesinde istatistiki olarak önemli bulunmuștur 
düşük TON içeriği ise kontrol uygulamasında ortaya çıkmıștır. Zeytin karasu uygulamaları toprağın labil $\mathrm{N}$ kaynakları olan mikrobiyal biyokütle-N (MB-N) ve inorganik $\mathrm{N}$ (INOR-N) miktarlarını da istatistiki anlamda etkilemiștir. En yüksek MB-N miktarları genelde 50 ve $100 \mathrm{~m}^{3} \mathrm{ha}^{-1}$ uygulamalarında $(\mathrm{HI}, \mathrm{H} 2, \mathrm{El}, \mathrm{E} 2$ ve $\mathrm{II})$, en düșük $M B-N$ miktarları ise kontrol ve E3 uygulamalarında

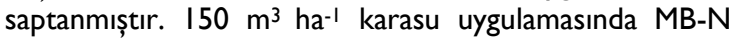
miktarlarında bir azalma kaydedilmiștir. İnorganik $N$ miktarları (iNOR-N) incelendiğinde ise kontrol toprağın en yüksek iNOR-N miktarlarına sahip olduğu ve karasu uygulamaları ile iNOR-N miktarlarının azaldığı görülmüștür. Labil N kaynaklarının, toplam azota oranları da hesaplanmıș ve sonuçlar yine Çizelge 4'de verilmiștir. En yüksek MB-N/TON oranları karasu uygulamalarının I. ve 2. dozlarında, en düșük oranlar ise kontrol ve en yüksek karasu uygulamalarında saptanmıștır. MB-N/TON oranları \%5.03 ila \%10.52 arasında değișmiștir. INORN/TON oranlarında ise durum tamamen farklı çıkmıștır. En yüksek iNOR-N/TON oranları kontrol ve $\mathrm{H} 3$ uygulamalarında çıkarken diğer uygulamalar aynı istatistiki grup içerisinde yer almıșlardır. Toprakların iNORN/TON oranları \%0.28 ila \%0.39 arasında yer almıștır.

Zeytin karasu uygulamaları ile toprakların TON içeriği kontrole oranla artmıștır. Fakat arıtılan karasuların toprağın azot kapsamı üzerine etkisi daha az olmuștur. Bunun nedeni arıtma ile azotun büyük bir kısmının giderilmiș olmasından kaynaklanmıștır. Toprağın toplam azot bütçesine en büyük katkıyı \%8 ile $\mathrm{H} 3$ uygulaması yapmıștır. Piotrowska ve ark. (20II) tarafından yapılan bir çalıșmada ise $80 \mathrm{~m}^{3} \mathrm{ha}^{-1}$ düzeyinde toprağa verilen defenolize karasuyun toprağın TON içeriğini kontrole oranla I.4 kat daha fazla artırdığı saptanmıștır. Toprağın azot bilançosundaki artıș toprak mikroorganizmalarını da uyarmıș ve MB-C sonuçlarına benzer șekilde MB-N miktarı da uygulamalardan etkilenmiștir. Bu parametre de düșük karasu uygulamalarında daha yüksek değerlere sahip olmuștur. Karasuyun 50 ve $100 \mathrm{~m}^{3}$ ha-1 uygulamalarının topraktaki mikrobiyal biyokütleyi ve buna bağlı olarak bu hücrelerdeki $C$ ve $N$ miktarlarını da artırdığı anlașılmaktadır. Düșük karasu dozlarındaki mikrobiyal biyokütlenin artıșını, bu toprakların diğerlerine oranla daha yüksek olan $M B-C / T O C$ ve $M B-$ N/TON oranları da teyit etmektedir (Çizelge 3 ve 4). Bu oranlar, toprakta herhangi bir müdahaleden sonra mikrobiyal biyokütle ve biyokimyasal aktivitelerde meydana gelen değișimlerin önemli göstergeleridir. Bir toprağı sağlıklı veya sağlıksız olarak nitelendirebilmek için referans değerler olmamasına karșın, yüksek MB-C/TOC ve MB-N/TON oranları, topraktaki mikroorganizmaların çoğunun iyi koșullar altında yașadığını göstermektedir. Genellikle bu oranlar ne kadar düșük olursa, organik maddenin mineralize olma eğilimi de daha düșük olur (Sparling, 1992).

Karasu uygulanan topraklarda kontrol toprağa oranla TOC, TON, ÇÖZ-C, MB-C ve MB-N miktarları artmasına karșın, iNOR-N miktarları azalmıștır. Bu durum, yüksek $\mathrm{C} / \mathrm{N}$ oranlarından dolayı (Çizelge I) karasu uygulaması ile toprakta $\mathrm{N}$-immobilizas yonunun meydana geldiğini ve toprağın inorganik azot havuzunun küçüldüğünü göstermektedir. $\mathrm{C} / \mathrm{N}$ oranı 25 'in üzerinde olan organik materyallerin toprakta ayrıșabilmeleri için ihtiyaç duyulan azot, topraktaki inorganik $N$ kaynaklarından karșılanmaktadır (Robertson ve Groffman, 2007). Karasu uygulanan topraklarda Nimmobilizasyonunun meydana geldiği, bu topraklarda kontrole oranla daha düșük iNOR-N/TON oranlarının ortaya çıkmasından da anlașılmaktadır (Çizelge 4). Ayrıca artan karasu dozlarına bağlı olarak iNOR-N miktarlarının da artmasının nedeni, azalan organik madde ayrıșmasından dolayı havuzdan daha az inorganik azotun kullanılmasıdır. Yüksek karasu düzeylerinde topraktaki iNOR-N miktarının azalmasının bir diğer nedeni de, yüksek miktarda çözünebilir organik $C$ içeren atıkların mineralizasyonu sırasında önemli miktarda $\mathrm{CO}_{2}$ 'in açığa çıkmasına bağlı olarak $\mathrm{O}_{2}$ konsantrasyonunun azalmasıdır. Bu da ortaya çıkan indirgen koșullar nedeniyle nitrifikasyonun azalmasına neden olabilmektedir (Bernal ve ark., 1998).

\section{Zeytin Karasu Uygulamalarının Toprağın Bazı Kimyasal Özellikleri Üzerine Etkisi}

Zeytin karasu uygulamalarının toprağın pH'sı, elektriksel iletkenliği (EC) ve bazı bitki besin maddelerinin alınabilir miktarları üzerine etkisi Çizelge 5'de verilmiștir.

Araștırma topraklarının $\mathrm{pH}$ değerleri 7.06 ile 7.35 arasında değișiklik göstermiștir. Sadece $\mathrm{H} 2$ ve $\mathrm{H} 3$ uygulamalarında kontrole oranla daha yüksek $\mathrm{pH}$ değerleri saptanmıș, tüm $\mathrm{E}$ ve $\mathrm{I}$ uygulamalarında ise toprakların $\mathrm{pH}$ değerleri kontrol toprağınki ile aynı istatistiki grupta yer almıștır. Oldukça yüksek pH'ya (I0.5I) sahip olan ekonomik arıtılmıș karasu, toprakların pH'sını yükseltmemiș, orta asit ve kuvvetli asit reaksiyondaki ham ve ileri arıtılmıș karasu ise topraktaki karbonat alkaliliği tarafından nötralize edilerek toprak pH'sını düșürememiștir. Mechri ve ark.' da (2007) ortalama 5.5 pH'ya sahip zeytin karasu uygulaması ile toprakların pH'sının azalmamasını bu nedene bağlamıșlardır. Sonuç olarak zeytin karasu uygulamalarının toprakların $\mathrm{pH}$ 'sında meydana getirdiği hafif derecedeki değișimler, tüm toprakların $\mathrm{pH}$ derecelendirmesini değiștirmemiș ve kontrol dahil tüm topraklar nötr reaksiyonlu topraklar sınıfına girmișlerdir.

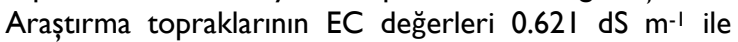
$0.830 \mathrm{dS} \mathrm{m}^{-1}$ arasında değișiklik göstermiștir. Karasu uygulamaları toprakların EC değerlerini kontrole oranla artırmıștır. En yüksek EC değerleri en yüksek karasu uygulamalarında (H3, E3 ve i3) belirlenmiștir. Zeytin karasu uygulamalarından sonra toprak EC'sinde meydana gelen artıșlar genellikle zeytin karasuyundaki yüksek tuz konsantrasyonlarından kaynaklanmaktadır. Mechri ve ark. (2007) söz konusu tuzluluğun kaynağının, zeytin karasuyunun temel iyonları olan $\mathrm{Na}+$ ve $\mathrm{SO}_{4}{ }^{-2}$ olduğunu ileri sürmüșlerdir. Toprakların elektriksel iletkenlik değerlerinde karasu uygulamalarından sonra hafif bir artıș 
Çizelge 5. Zeytin karasu uygulamalarının toprağın pH'sı, elektriksel iletkenliği (EC) ve bazı bitki besin maddelerinin alınabilir miktarları üzerine etkisi

\begin{tabular}{|c|c|c|c|c|c|c|c|c|c|}
\hline \multirow[b]{2}{*}{ Uyg. } & \multirow[b]{2}{*}{$\mathrm{pH}$} & \multirow[b]{2}{*}{$E C\left(\mathrm{dS} \mathrm{m} \mathrm{m}^{-1}\right)$} & \multicolumn{7}{|l|}{$(\mathrm{mg} \mathrm{kg-1})$} \\
\hline & & & $P$ & $\mathrm{~K}$ & $\mathrm{Ca}$ & $\mathrm{Na}$ & $\mathrm{Zn}$ & $\mathrm{Fe}$ & $\mathrm{Cu}$ \\
\hline $\mathrm{K}$ & $7.16 b^{*}$ & $0.621 b^{*}$ & $18.7 b^{*}$ & $533 d^{*}$ & $2390 a^{*}$ & $17 c^{*}$ & $2.2 b^{*}$ & $2.4 a b^{*}$ & $0.68 b^{*}$ \\
\hline $\mathrm{HI}$ & $7.17 \mathrm{~b}$ & $0.7 / 3 a b$ & $21.9 \mathrm{ab}$ & $567 c$ & 2058 b & 19 bc & $2.1 \mathrm{~b}$ & $2.9 \mathrm{ab}$ & $0.86 \mathrm{ab}$ \\
\hline $\mathrm{H} 2$ & $7.35 \mathrm{a}$ & $0.717 \mathrm{ab}$ & $24.8 \mathrm{a}$ & $627 \mathrm{~b}$ & $2124 a b$ & $23 a b$ & $1.9 \mathrm{~b}$ & $2.6 \mathrm{ab}$ & $0.78 a b$ \\
\hline $\mathrm{H} 3$ & $7.25 \mathrm{ab}$ & $0.822 \mathrm{a}$ & $25.1 \mathrm{a}$ & $722 \mathrm{a}$ & $2240 \mathrm{ab}$ & $29 a$ & $1.7 \mathrm{~b}$ & $1.9 \mathrm{~b}$ & $0.64 \mathrm{~b}$ \\
\hline EI & $7.06 \mathrm{~b}$ & $0.759 a b$ & $21.1 \mathrm{ab}$ & $578 c$ & 2385 a & $23 \mathrm{ab}$ & $2.1 \mathrm{~b}$ & $3.6 \mathrm{a}$ & $0.94 \mathrm{a}$ \\
\hline E2 & $7.14 \mathrm{~b}$ & $0.805 \mathrm{ab}$ & $21.6 \mathrm{ab}$ & $644 b$ & $2556 \mathrm{a}$ & $28 \mathrm{a}$ & $2.1 \mathrm{~b}$ & $3.0 \mathrm{ab}$ & $0.87 \mathrm{ab}$ \\
\hline E3 & $7.12 \mathrm{~b}$ & $0.822 \mathrm{a}$ & $22.2 \mathrm{ab}$ & $710 \mathrm{a}$ & 2458 a & $33 \mathrm{a}$ & $2.0 \mathrm{~b}$ & $3.0 \mathrm{ab}$ & $0.84 \mathrm{ab}$ \\
\hline ì & $7.08 \mathrm{~b}$ & $0.704 a b$ & $20.2 \mathrm{ab}$ & $590 c$ & 2423 a & $21 \mathrm{~b}$ & $2.7 \mathrm{ab}$ & $2.9 \mathrm{ab}$ & $0.80 a b$ \\
\hline i2 & $7.15 \mathrm{~b}$ & $0.767 \mathrm{ab}$ & $20.1 \mathrm{ab}$ & $658 b$ & 2307 a & $30 \mathrm{a}$ & $3.4 \mathrm{a}$ & $3.4 \mathrm{ab}$ & $0.82 \mathrm{ab}$ \\
\hline ¡3 & $7.16 \mathrm{~b}$ & $0.830 \mathrm{a}$ & $20.3 \mathrm{ab}$ & $705 \mathrm{a}$ & $2323 \mathrm{a}$ & $37 \mathrm{a}$ & $3.8 \mathrm{a}$ & $3.1 \mathrm{ab}$ & $0.84 \mathrm{ab}$ \\
\hline
\end{tabular}

*: Uygulamalar arasındaki farklar \% I seviyesinde istatistiki olarak önemli bulunmuștur

saptansa da bu artış topraklarda herhangi bir tuzluluk tehlikesine yol açmamıștır.

Zeytin karasu uygulamaları, topraktaki alınabilir bitki besin maddelerinin birçoğu üzerinde de istatistik anlamda önemli değișikliklere neden olmuștur. En yüksek alınabilir P miktarları $\mathrm{H} 2$ ve $\mathrm{H} 3$, en yüksek alınabilir $\mathrm{K}$ miktarları ise $\mathrm{H} 3$, E3 ve i3 uygulamalarında belirlenmiștir. Ham karasuyun arıtılmıș karasulara oranla daha fazla olan toplam $\mathrm{P}$ içeriği, toprakların $\mathrm{P}$ miktarını da etkilemiș ve orta $\left(100 \mathrm{~m}^{3} \mathrm{ha}^{-1}\right)$ ve yüksek düzeyde $\left(150 \mathrm{~m}^{3} \mathrm{ha}^{-1}\right)$ ham karasu uygulamasının yapıldığı topraklarda daha fazla alınabilir $P$ miktarlarının ortaya çıkmasına neden olmuștur. Piotrowska ve ark.' da (20ll) $80 \mathrm{~m}^{3} \mathrm{ha}^{-1}$ düzeyinde verdikleri ham karasuyun, kontrole oranla toprakların alınabilir $P$ miktarlarını yaklașık 2 kat artırdığını bildirmișlerdir. Diğer önemli bir bitki besin maddesi olan potasyum ise artan tüm karasu dozlarına bağlı olarak doğrusal bir artıș göstermiștir. Zeytin karasuyu uygulaması ile toprağın alınabilir $\mathrm{K}$ içeriğindeki artıșlar birçok araștırıcı tarafından da saptanmıștır (Mechri ve ark., 2007; Magdich ve ark., 20I3; Gargouri ve ark., 2014). Toprakların alınabilir Ca kapsamları ham karasu uygulanmıș topraklarda kontrole oranla bir miktar azalırken diğer uygulamalarda artmıștır. En yüksek karasu uygulamaları toprakların alınabilir $\mathrm{Na}$ içeriklerini artırmıștır. Özellikle alkali toprakların olușmasında etkili bir element olan sodyumun yüksek karasu düzeylerinde toprakta biriktiği anlașılmaktadır. Zeytin karasuyu uygulamalarına bağlı olarak topraklarda meydana gelen alınabilir Na artıșları Belaqziz ve ark. (2016) tarafından da bildirilmiștir. Magdich ve ark. (2013) 3 yıl üst üste $200 \mathrm{~m}^{3}$ ha-1 zeytin karasuyu uyguladıkları toprakta, 3. uygulamadan sonra kontrole oranla yaklașık 3 kat daha fazla $\mathrm{Na}$ konsantrasyonu saptamıșlardır. Bu çalıșmada da kontrole oranla karasu uygulanmıs, topraklarda ortalama I.9 kat daha fazla $\mathrm{Na}$ konsantrasyonunun saptanması, devamlı uygulamalarda topraklarda $\mathrm{Na}$ birikimi açısından bir sorun olușabileceğini göstermektedir. Diğer besin elementlerin miktarlarında ise karasu uygulamalarına bağlı olarak çok önemli değișiklikler ortaya çıkmamıș, toprakların önemli bir kısmı kontrol ile aynı istatistiki grup içerisinde yer almıștır.

\section{SONUÇ}

Araștırmada sonuç olarak, kumlu tın bünyeli bir toprağa uygulanan zeytin karasu uygulamalarının toprağın $C$ ve $N$ dinamiği ile ilgili bazı kimyasal ve biyolojik parametreleri istatistiki anlamda etkilediği anlașılmıștır. Gerek arıtılmıș ve gerekse arıtılmamıș zeytin karasu uygulamaları toprağın TOC, TON, ÇÖZ-C, MB-C ve MB-N miktarlarını artırmıș fakat iNOR-N havuzunu küçültmüștür. Arıtılmamıș ham zeytin karasu uygulamalarının, toprakların TOC, TON ve yarayıșlı $P$ içeriklerini arıtılmıș karasulara oranla daha fazla artırdığı saptanmıștır. Bu durum, arıtma ile karasuyun kimyasal özelliklerinin önemli bir șekilde değișmesinden ve özellikle $\mathrm{C}, \mathrm{N}$ ve $\mathrm{P}$ miktarlarının azalmasından kaynaklanmıștır. Toprakların alınabilir $\mathrm{K}$ kapsamları ise tüm karasu uygulamaları ile önemli miktarda artmıștır. Zeytin karasu uygulamaları toprağın $M B-C$ ve $M B-N$ miktarlarını da artırmış fakat karasu dozlarının artıșına bağlı olarak miktarlarında bir azalma kaydedilmiștir. En yüksek MB-C/TOC, ÇÖZ-C/TOC, ve MB-N/TON oranları karasu uygulamalarının ilk dozlarında, en yüksek iNOR-N/TON oranları ise kontrol ve $\mathrm{H} 3$ uygulamalarında saptanmıștır. Bu sonuçlar karasuyun 50 ve $100 \mathrm{~m}^{3} \mathrm{ha}^{-1}$ uygulamalarında topraktaki mikrobiyal biyokütlenin arttığını fakat $150 \mathrm{~m}^{3}$ ha-1 karasu uygulamasında topraktaki $\mathrm{C}$ ve $\mathrm{N}$-dinamiğinin olumsuz etkilendiğini ortaya çıkarmıștır. Yine bu düzeylerdeki karasuyun uzun süreli kullanımlarında toprakta $\mathrm{Na}$ birikimine neden olabileceği ve tuz miktarını artırılabileceği düșünülmektedir. Bu çalıșmada herhangi bir bitki yetiștirilmediği için, arıtılmamıș karasuyun yüksek fenol içeriğinin bu toprak koșullarında tohum çimlenmesi ve bitki gelișimi açısından nasıl bir etkisinin olacağı bilinmemektedir. Bu açıdan zeytin karasuyunun tarım alanlarında kullanımında fenol içeriğinin ve yüksek organik $C$ yükünün düșürüldüğü arıtılmıș karasuyun 
tercih edilmesi gerekmektedir. Zeytin karasuyu ile yapılan çalıșmalar ülkemizde yeterli olmayıp farklı fiziksel ve kimyasal özelliklere sahip topraklar ve farklı bitkiler için çeșitli bakıș açılarına sahip çalıșmaların yapılması gerekmektedir. Ancak bu șekilde bu tür atıkların çok yönlü etkileri ile birlikte değerlendirilerek tarım topraklarında kullanılması ile ilgili tavsiyeler geliștirilebilir.

\section{KAYNAKLAR}

Anonim (1978) Torf für Gartenbau und Landwirtschaft (DIN I I542).

Anonim (20I5) Türkiye İstatistik Yıllığı. Türkiye İstatistik Kurumu Matbaası, Ankara.

Belaqziz M, El-Abbassi A, Lakhal EK, Agrafioti E, Galanakis CM (2016) Agronomic Application of Olive Mill Wastewater: Effects on Maize Production and Soil Properties. Journal of Environmental Management 171:158-165.

Bernal MP, Paredes C, Sanchez-Monedero MA, Cegarra J (1998) Maturity and Stability Parameters of Composts Prepared With a Wide Range of Organic Wastes. Bioresource Technology 63:91-99.

Black C A (1965) Methods of Soil Analysis, Part I-2., American Society of Agronomy, Inc., Publisher. Madison Wisconsin.

Böhme L, Böhme F (2006) Soil Microbiological and Biochemical Properties Affected by Plant Growth and Different Long-Term Fertilization. European Journal of Soil Biology 42:1- 12.

Bouyoucos GJ (1962) A Recalibration of the Hydrometer Method for Making Mechanical Analysis of the Soils. Agronomy Journal 4(9): 419-434.

Bremner, JM (1965) Total Nitrogen. In: Black CA (ed), Methods of Soil Analysis. Part-2, American Society of Agronomy Inc, Publisher Madison, Wisconsin, I I49. II 78.

Brunetti G, Senesi N, Plaza C (2007) Effects of Amendment With Treated and Untreated Olive Oil Mill Wastewaters on Soil Properties, Soil Humic Substances and Wheat Yield. Geoderma I38:|44152.

Demisie W, Liu Z, Zhang M (2014) Effect of Biochar on Carbon Fractions and Enzyme Activity of Red Soil. Catena $121: 2 \mid 4-221$.

FAO (2016) Food and Agriculture Organization of the United Nations Statistics Division. Web: http://www.fao.org/faostat/en/\#data/QD Erișim Tarihi: 27.04.2018.

Gargouri K, Rouina BB, Mechichi T, Kallel M (2014) Effects of Olive Mill Wastewater on Soil Nutrients Availability. International Journal of Interdisciplinary and Multidisciplinary Studies (IJIMS) 2(I):I75-I83.

Haynes RJ (2000) Labile Organic Matter as an Indicator of Organic Matter Quality in Arable and Pastoral Soils in New Zealand. Soil Biology \& Biochemistry 32:211- 219.

Hocaoğlu SM (20I5) Zeytin Sektörü Atıklarının Yönetimi Projesi. Çevre ve Șehircilik Bakanlığı, Çevre Yönetimi Genel Müdürlüğü, Nihai Rapor, 335.

Huang JY, Song, CC (2010) Effects of Land Use on Soil Water Soluble Organic C and Microbial Biomass C
Concentration in the Sanjiang Plain in Northeast China. Acta Agriulturae Scandivanica Section B Soil Plant 60:182-188.

Jackson ML (1967) Soil Chemical Analysis, Prentice Hall of India Private Limited, New Delhi.

Jones DL, Willett, VB (2006) Experimental Evaluation of Methods to Quantify Dissolved Organic Nitrogen (DON) and Dissolved Organic Carbon (DOC) in Soil. Soil Biology \& Biochemistry 38(5):991-999.

Kandeler E, Gerber H (1988) Short-term Assay of Soil Urease Activity Using Colorimetric Determination of Ammonium. Biology and Fertility of Soils 6(1):68-72.

Lindsay WL, Norvell WA (1978) Development of a DTPA Soil Test for Zn, Fe, Mn and Cu. Soil Science Society of America Journal 42(3):42 I-428.

Magdich S, Ahmed CB, Jarboui R, Rouina BB, Boukhris $M$, Ammar E (20I3) Dose and Frequency Dependent Effects of Olive Mill Wastewater Treatment on the Chemical and Microbial Properties of Soil. Chemosphere 93(9): 1896-1903.

Mechri B, Ben Mariem F, Baham M, Ben Elhadj S, Hammami M (2009) Change in Soil Properties and the Soil Microbiological Community Following Land Spreading of Olive Mill Wastewater Affects Olive Trees Key Physiological Parameters and the Abundance of Arbuscular Mycorrhizal Fungi. Soil Biology \& Biochemistry 40:152-16I.

Mechri B, Echbili A, Issaoui M, Braham M, Elhadj SB, Hammamia M (2007) Short-term Effects in Soil Microbial Community Following Agronomic Application of Olive Mill Wastewaters in a Field of Olive Trees. Applied Soil Ecology 36:216-223.

Mekki A, Dhouib A, Sayadi S (2006) Changes in Microbial and Soil Properties Following Amendment With Treated and Untreated Olive Mill Wastewater. Microbiological Research 161:93-101.

Moraetis D, Stamati FE, Nikolaidis NP, Kalogerakis N (20II) Olive Mill Wastewater Irrigation of Maize: Impacts on Soil and Groundwater. Agricultural Water Management 98(7): I I 25-I I 32.

Olsen SR, Sommers EL (1982) Phosphorus Soluble in Sodium Bicarbonate. In: Page AL, Miller RH, Keeney DR (Eds.), Methods of Soil Analysis, Chemical and Microbiological Properties, Part 2, American Society of Agronomy, Madison, 404-430.

Piotrowska A, lamarino G, Rao MA, Gianfreda L (2006) Short-term Effects of Olive Mill Waste Water (OMW) on Chemical and Biochemical Properties of a Semiarid Mediterranean Soil. Soil Biology \& Biochemistry 38:600-610.

Piotrowska A, Antonietta Rao M, Scotti R, Gianfreda L (20II) Changes in Soil Chemical and Biochemical Properties Following Amendment With Crude and Dephenolized Olive Mill Waste Water (OMW). Geoderma 161:8-17.

Pratt PF (1965) Chemical and Microbiological Properties. In: Black CA (Ed.), Methods of Soil Analysis. Part 2 American Society of Agronomy, Inc. Pub. Agron. Series, No. 9 Madison, Wisconsin. 
Rauterberg E, Kremkus F (I95I) Bestimmung Von Gesamthumus und Alkalilöslichen Humusstoffen im

Boden. Zeitschrift für Pflanzenernährung, Düngung, Bodenkunde 54(3):240-249.

Robertson GP, Groffman, PM (2007) Nitrogen Transformations. In: Paul EA (ed.), Soil Microbiology, Ecology, and Biochemistry, Burlington, Academic Press, Elsevier, 34I-387.

Scharpf HC, Wehrmann J (1976) Importance of Soil Mineral N Supply at the Start of the Growing Season for Assessing $N$ Fertilizer Requirements of Winter Wheat. Landwirtschaftliche Forschung, Sonderheft 32(I): $100-114$.

Schlichting E, Blume HP (1966) Bodenkundliches Praktikum. Verlag Paul Parey, Hamburg und Berlin.

Sierra J, Martí E, Garau MA, Cruanas R (2007) Effects of the Agronomic Use of Olive Oil Mill Wastewater Field Experiment. Science of the Total Environment 378: 90-94.
Sparling G (1992) Ratio of Microbial Biomass C to Soil Organic $C$ as a Sensitive Indicator of Changes in Soil Organic Matter. Australian Journal of Soil Research 30:195-197.

Tsagaraki E, Lazarides N, Petrotos KB (2007) Olive Mill Wastewater Treatment. In: Oreopoulou V, Russ W (Eds.), Utilization of By-products and Treatment of Waste in the Food Industry, LLC, NY, USA, Springer Science+Business Media, I32-I57.

Vance ED, Brookes PC, Jenkinson DS (1987) An Extraction Method for Measuring Soil Microbial Biomass C. Soil Biology \& Biochemistry 19:703 707.

Yay ASE, Oral HV, Onay TT, Yenigün O (20I2) A Study on Olive Mill Wastewater Management in Turkey: A Questionnaire and Experimental Approach. Resources, Conservation and Recycling 60:64-7I. 